\title{
Mgr Paulina SzUlc-Fischer
}

\author{
Uniwersytet Gdański \\ Wydział Ekonomiczny \\ email: p.szulc@ug.edu.pl
}

\section{WPŁYW FINANSOWANIA ZE ŚRODKÓW UNII EUROPEJSKIEJ NA JAKOŚĆ ŻYCIA MIESZKAŃCÓW}

Słowa kluczowe: jakość życia, produkt krajowy brutto per capita, Unia Europejska

Abstrakt. Celem artykułu jest przedstawienie poziomu jakości życia mieszkańców Unii Europejskiej na przykładzie wybranych regionów. Analiza dotyczy ekonomicznych wskaźników warunków jakości i poziomu życia, tzw. wskaźnik rozwoju społecznego (HDI) oraz poziomu produktu krajowego brutto per capita $\mathrm{w}$ wybranych regionach państw UE. Pojęcie jakości życia ma charakter interdyscyplinarny. Najczęściej definiowane jest jako subiektywne postrzeganie poziomu życia przez pryzmat stanu zdrowia, relacji rodzinnych, pracy, zamożności oraz poziomu edukacji.

European Union funding impact on the quality of life

Keywords: quality of life, gross domestic product per capita, European Union

Abstract. The article presents concepts and measures of quality of life in European Union regions. Conclusions were based on the results of global Human Development Index (HDI) ranking in recent years and gross domestic product per capita in EU regions. The quality of life definition include basic aspect like: human condition, family, work, education.

\section{Wprowadzenie}

Termin ,jakość życia”, w literaturze przedmiotu, do tej pory nie został jednoznacznie określony ze względu na jego interdyscyplinarny charakter. Od lat z problemem sformułowania jednoznacznej definicji tego pojęcia zmagają się nauki takie jak socjologia, psychologia czy ekonomia. Na wstępie rozważań należy podkreślić, że istnieje wiele metod pomiaru poziomu i jakości życia danego społeczeństwa, wśród nich należy wymienić produkt krajowy brutto, najczęściej stosowany ekonomiczny miernik. PKB jest jednym z elementów wykorzystywanych w analizie znacznie 
bardziej rozbudowanych wskaźników jakości życia (m.in. wskaźnik rozwoju społecznego, wydajności środowiskowej, szczęśliwej planety czy ubóstwa). W literaturze przedmiotu opisywany jest również odrębny sposób mierzenia jakości życia, który dotyczy jej subiektywnego postrzegania. Bazuje na analizie opinii i zachowań badanych mieszkańców danego kraju lub regionu. Tak przeprowadzona analiza dotyczy jedynie subiektywnego postrzegania warunków i jakości życia. Każdy człowiek ma własny, odrębny pogląd na temat swoich oczekiwań, potrzeb a tym samym również warunków życia. Dlatego też bardzo często stosuje się atrybuty jakości życia, do których należą: ocena pozycji społecznej, ocena stanu zdrowia, poziom wykształcenia, edukacja, sytuacja finansowa jednostki, relacje rodzinne oraz ocena zdrowia psychicznego. Najważniejszym czynnikiem dobrego życia staje się własna ocena swojego życie i odpowiedź na pytanie: ,czy je lubimy, czy nie” (Diener, Oishi, Lucas, 2002).

Trudność w badaniu jakości życia, bez względu na wybór wskaźnika, polega na podjęciu próby estymacji parametrów zarówno pod względem obiektywnym jak i subiektywnym. Obiektywna ocena jakości życia bardzo często utożsamiana jest z pojęciem poziomu życia. Analizując elementy obiektywne wykorzystuje się najczęściej dane pochodzące ze statystki publicznej, do której należą m.in. miesięczne wynagrodzenie, wielkość powierzchni mieszkalnej czy też liczba oszczędności przypadająca na jedno gospodarstwo domowe. Dane te są systematycznie gromadzone a następnie podawane do informacji publicznej m.in. przez Główny Urząd Statystyczny czy Eurostat. Subiektywna ocena jakości życia będzie odbywała się w ramach określonego systemu wartości oraz określonych warunkach społecznych, gospodarczych i politycznych. W Polsce, na podstawie badań ankietowych, takie dane gromadzi m.in. Instytut Rynku Wewnętrznego i Konsumpcji.

\section{Pojęcie jakości życia i jego pomiar}

Najczęściej używaną definicją i jednocześnie powszechnie cytowaną jest wykładnia Quality of Life Group Światowej Organizacji Zdrowia: ,postrzeganie przez jednostkę jej pozycji w życiu w kontekście kultury i systemów wartości akceptowanych przez społeczeństwo, w jakich żyje, oraz w relacji do jej celów życiowych, oczekiwań, zainteresowań” (WHOQOL Group, 1995).

Podając bardzo ogólną definicję ,jakości” możemy powiedzieć, że jest to „zgodność z wymaganiami” lub „zaspokojenie aktualnych bądź przyszłych potrzeb” (Tomcz-Tołkacz, 2003). Dlatego też najczęściej jakość życia jest oceniana na podstawie zbioru pewnych kryteriów, odgórnie przyjętych i jednakowych dla wszystkich 
badanych obszarów, do których należą: „,bogactwo przeżyć, poziom świadomości, poziom aktywności, twórczość, współuczestnictwo w życiu społecznym. Im większe jest ich spełnienie, tym wyższa jest jakość życia” (Tomaszewski, 1984).

Przytaczając inną definicję omawiane zagadnienie możemy nazwać poziomem zaspokojenia potrzeb duchowych i materialnych człowieka. Jakość życia to „stopień zaspokojenia wymagań określający poziom materialnego i duchowego bytu jednostek i całego społeczeństwa, stopień spełnienia oczekiwań umownej normalności w działaniach i sytuacji codziennego życia jednostek i społeczeństwa" (Kolman, 2000). Warto podkreślić również fakt, że jakość życia może zostać ujęta jedynie w wymiarze psychologicznym. W takim wypadku punktem odniesienia są pozytywne oraz negatywne przeżycia człowieka. Każdy człowiek zbiera życiowe doświadczenia, które może nabyć w wyniku odbierania bodźców zmysłowych, odczuwanych emocji i nastroju. Możemy zatem stwierdzić, iż jakość życia nierozerwalnie związana jest ze sferą przeżyć. Istotniejsze od poziomu zaspokojenia potrzeb jest to, co człowiek czuje.

Reasumując , jakość w odniesieniu do życia ludzkiego bardzo często jest uzależniona od perspektywy podmiotu określającego. Dlatego też podczas badania warto wziąć pod uwagę z góry założone kryteria oceny, będące jednakowymi dla wszystkich, np. warunki ekonomiczne (tj. PKB per capita, średnie wynagrodzenie).

\section{Polityka regionalna Unii Europejskiej}

W literaturze przedmiotu pojęcie „regionu” definiowane jest jako zwarta przestrzeń „będąca częścią większego terytorium, spójna wewnętrznie” (Meyer, 1995). Pierwsze wzmianki dotyczące polityki regionalnej Unii Europejskiej pochodzą z 1957 roku. Zostały opisane w Traktacie ustanawiającym Europejską Wspólnotę Gospodarczą (EWG) (EuroLex, 2017). W roku następnym powołano Europejski Fundusz Społeczny (EFS), a w 1975 roku Europejski Fundusz Rozwoju Regionalnego (EFRR). Natomiast podstawy prawne polityki regionalnej zostały opisane w jednolitym akcie europejskim z 1986 roku (Komisja Europejska, 2014). Europejski Fundusz Rozwoju Regionalnego został powołany na rzecz rozwoju potencjału społeczno-gospodarczego krajów członkowskich Unii Europejskiej, a szczególnie regionów, które są słabiej ekonomicznie i gospodarczo rozwinięte. Środki Europejskiego Funduszu Rozwoju Regionalnego są w głównej mierze przeznaczone na: projekty, które stawiają sobie za cel zwiększanie zatrudnienia, rozwój przedsiębiorczości, rozbudowę infrastruktury i inwestycje w fundusze nieruchomości, wzrost innowacyjności i konkurencyjności gospodarczej, poprawę ochrony środowiska, placówki opiekuńczo-medyczne czy 
aktywizację współpracy między sąsiadującymi regionami państw członkowskich (EFRR, 2017). Polska należy do beneficjentów EFRR w ramach programów: Program Operacyjny Infrastruktura i Środowisko, Program Operacyjny Innowacyjna Gospodarka, 16 Regionalnych Programów Operacyjnych dla Województw, Program Operacyjny Rozwój Polski Wschodniej, Program Operacyjny Pomoc Techniczna, Programy Operacyjne Europejskiej Współpracy Terytorialnej. EFRR przyczynia się do wzmocnienia spójności gospodarczej i społecznej przy jednoczesnym zmniejszaniu dysproporcji występujących między regionami. Finansowanie w głównej mierze dotyczy: inwestycji przyczyniających się do tworzenia stałych miejsc pracy, inwestycji w infrastrukturę, np.: drogi, ekrany akustyczne, mosty, obiekty inżynieryjne, linie kolejowe, działania wspierające rozwój regionalny i lokalną pomoc techniczną (EFRR, 2017).

Wraz z akcesją kolejnych państw zmieniał się zakres polityki regionalnej oraz wysokość budżetu Unii Europejskiej. Wysokość budżetu - w planowanym okresie 2014- 2020 - wynosiła 351,8 mld euro, przy czym na kluczowe inwestycje przeznaczono około 100 mld euro, w tym 26,7 mld przeznaczono na wspieranie procesu przechodzenia na gospodarkę niskoemisyjną. Kluczowe inwestycje w latach 2014-2020 to:

- badania naukowe i innowacje,

- realizacja agendy cyfrowej,

- wsparcie na rzecz sektora małych i średnich przedsiębiorstw,

- gospodarka niskoemisyjną.

Środki polityki regionalnej Unii Europejskiej, prowadzonej w latach 2007-2012, przeznaczono na (Komisja Europejska, 2014):

- utworzenie 594 tys. miejsc pracy (w tym 262 tys. w sektorze MŚP),

- zainwestowanie w 198 tys. przedsiębiorstw sektora MŚP,

- udzielenie wsparcia blisko 78 tys. podmiotów rozpoczynających działalność gospodarczą,

- sfinansowanie 61 tys. projektów badawczych,

- zapewnienie zasięgu łączności szerokopasmowej prawie $5 \mathrm{mln}$ nowych użytkowników mieszkających w UE,

- udzielenie wsparcia na budowę 1208 km dróg i $1495 \mathrm{~km}$ linii kolejowych, co przyczyniło się do stworzenia transeuropejskiej sieci transportowej,

- podniesienie jakość życia mieszkańców obszarów miejskich przez zmodernizowany system dostarczania wody, z którego korzysta 3,2 mln mieszkańców, oraz zrównoważony transport.

Zakres polityki regionalnej przyjętej na lata 2014-2020 wraz z beneficjentami Europejskiego Funduszu Rozwoju Regionalnego (EFRR) i Europejskiego Funduszu 
Społecznego (EFS) obejmuje 274 regiony Unii Europejskiej (Komisja Europejska, 2014). We wskazanym okresie ze środków polityki regionalnej zapewniono finansowanie ze środków Funduszu Spójności w wysokości 65,3 mld euro w tym:

- w ramach Europejskiej Współpracy Terytorialnej - wysokość finansowania 10,2 mld euro;

- inicjatywy na rzecz zatrudnienia ludzi młodych - w wysokości 3,2 mld euro,

- finansowanie w postaci szczególnych dotacji na rzecz regionów najbardziej oddalonych i regionów o niskiej gęstości zaludnienia - w wysokości 1,6 mld euro.

Główne cele redystrybucji środków to poprawa jakości życia mieszkańców UE poprzez tworzenie nowych miejsc pracy oraz wspieranie działalności w szeroko pojmowanym obszarze badań naukowych, rozwoju oraz innowacji (Komisja Europejska, 2014).

\section{Jakość życia w regionach UE}

Definicja „produktu krajowego brutto” wskazuje, że jest to podstawowa miara stosowana $\mathrm{w}$ rachunkach narodowych, która określa pozycję gospodarczą danego państwa lub regionu. PKB to inaczej „całkowity dochód gospodarki narodowej” (Begg, Vernasca, Fischer, Dornbusch, 2011). Najczęściej miernik ten wykorzystywany jest do analizy wyników gospodarczych i cykli koniunkturalnych, ponadto ułatwia porównywanie danych w różnych walutach, choć kursy wymiany walut nie odzwierciedlają wszystkich różnic $\mathrm{w}$ poziomach cen poszczególnych państw (PKB na poziomie regionalnym 2017). Najnowsze dane dotyczące wysokości PKB na jednego mieszkańca (mierzona parytetem siły nabywczej, PPS) zostały przedstawione na rysunku 1. Zastosowanie PPS umożliwia porównanie siły nabywczej w różnych regionach państw członkowskich UE, w których stosuje się różne waluty oraz w których występują różne poziomy cen (Eurostat, 2017). Warto zauważyć, że w 2016 roku najwyższy poziom PKB per capita - znacząco odbiegający od poziomu pozostałych państw - odnotowano w Luksemburgu. Natomiast najniższy poziom PKB per capita występował w Bułgarii. Polska znalazła się w gronie pięciu państw o najniższym poziomie produktu krajowego brutto (w Polsce i na Węgrzech omawiany wskaźnik miał taką samą wartość). Omówione dane nie wskazują poziomu jakości życia. Dlatego też warto je porównać ze znacznie bardziej rozbudowanym miernikiem jakim jest m.in. wskaźnik rozwoju społecznego (HDI). Wskaźnik ten stosowany jest przez Organizację Narodów Zjednoczonych od 1993 roku, bierze za 
podstawę analizę długości życia mieszkańców, średnią liczbę lat edukacji oraz poziom dochodu mieszkańców.

Rysunek 1. PKB na jednego mieszkańca w PPS w 2016 roku

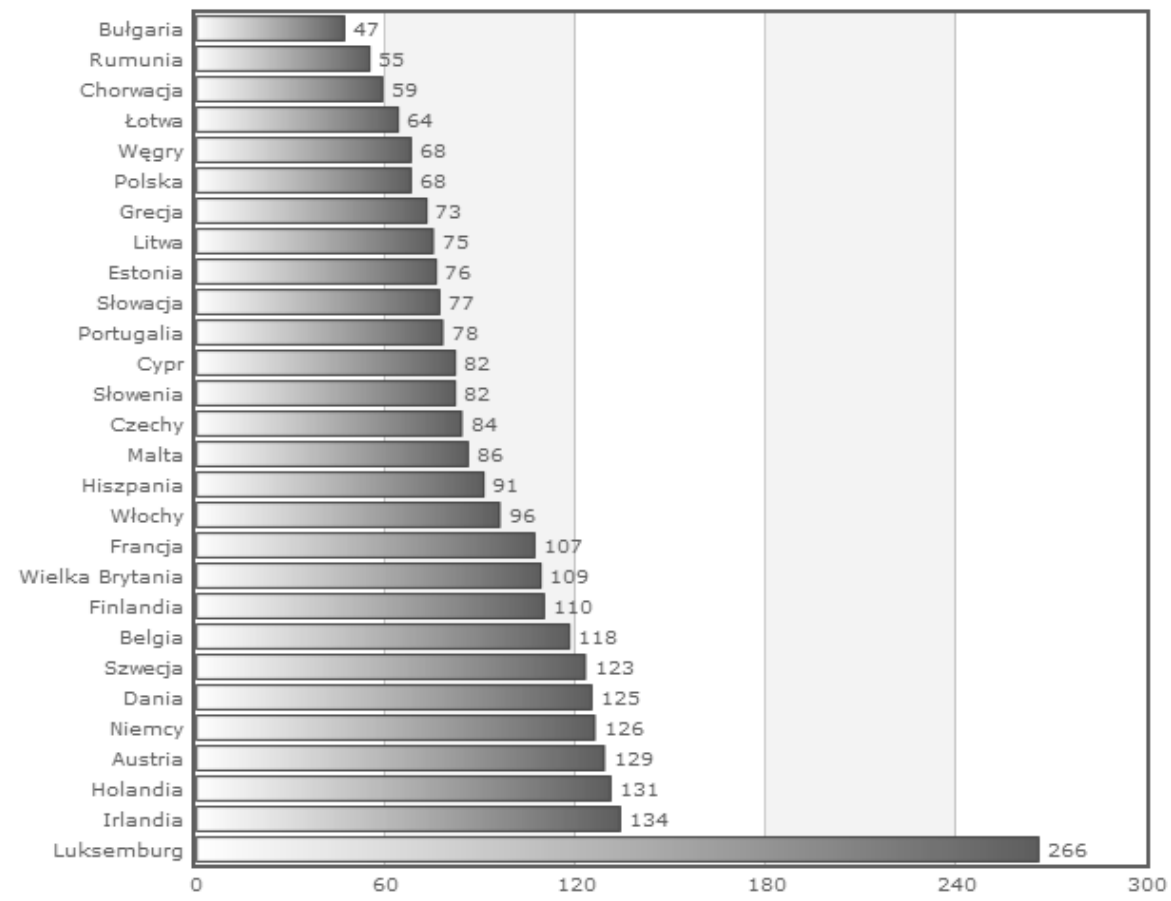

Źródło: Unia Europejska (2017).

Ranking HDI dzieli kraje na cztery grupy: bardzo wysoko rozwinięte, wysoko rozwinięte, średnio rozwinięte, słabo rozwinięte - wyniki rankingu zostały przedstawione w tabeli 1. W gronie dziesięciu najlepiej rozwiniętych państw znalazły się kraje o najwyższym poziomie PKB, m.in. Niemcy (miejsce 4), Dania (miejsce 5), Holandia (miejsce 7) (Human Development Index, 2017). W przywołanym rankingu Luksemburg zajmuje 20 miejsce wśród bardzo wysoko rozwiniętych państw świata. Według Wskaźnika Rozwoju Społecznego Polska zajmuje 36 miejsce i również sklasyfikowana jest jak kraj wysoko rozwinięty. Bułgaria zajmuje 56 miejsce i została najniżej sklasyfikowana w grupie państw wysoko rozwiniętych (UNDP, 2016). Porównując powyższe dane z rankingiem HDI, w 2016 roku kraje Europy Wschodniej, tj. Bułgaria, Rumunia, Łotwa zostały wyżej ocenione w klasyfikacji. Ponadto 
odnotowano wzrost wskaźnika rozwoju na Malcie, w Chorwacji i Irlandii, Polska w tym rankingu spadła o jedną pozycję.

Poszczególne regiony Unii Europejskiej zostały podzielone ze względu na poziom PKB. W regionach „słabiej rozwiniętych” produkt krajowy brutto na mieszkańca jest niższy niż 75\% średniej 27 państw Unii Europejskiej. Regiony będące w „okresie przejściowym” charakteryzują się w wysokością PKB na mieszkańca na poziomie większym bądź równym $75 \%$ średniej unijnej. Kraje osiągające powyżej 90\% PKB należą do państw „lepiej rozwiniętych” (Komisja Europejska, 2014).

Rysunek 2. Klasyfikacja regionów Unii Europejskiej

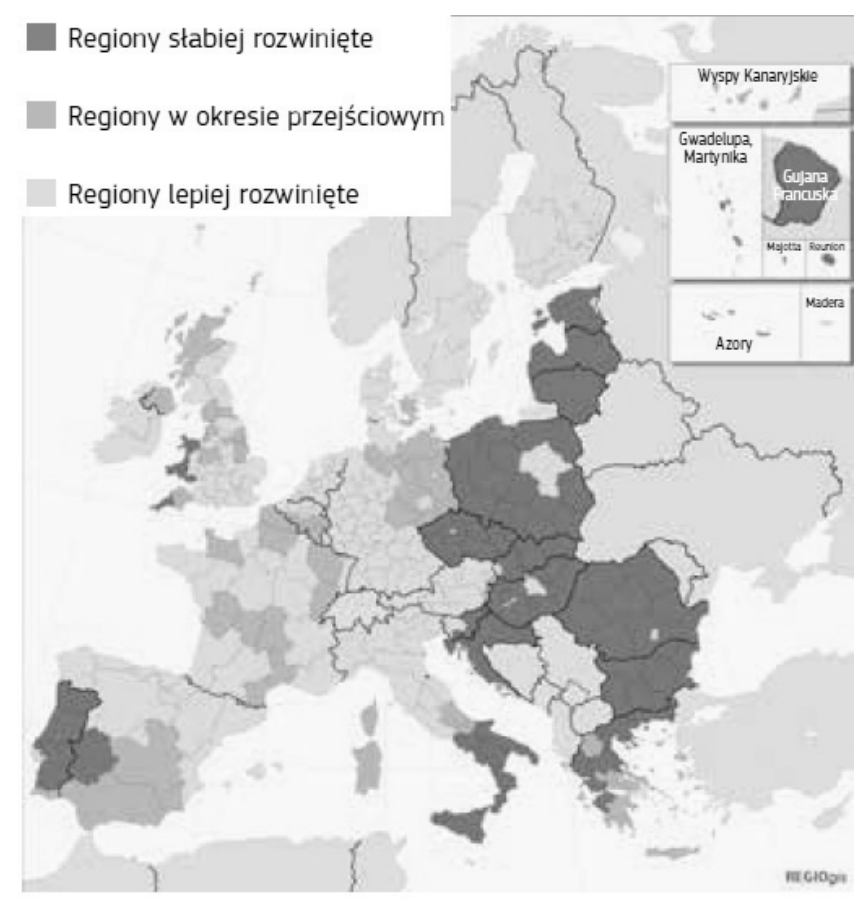

Źródło: Komisja Europejska (2014).

Szczegółowe informacje dotyczące wysokości produktu krajowego brutto (PPS na jednego mieszkańca) w najlepiej rozwiniętych regionach państw wyrażonego jako procent średniej UE przedstawiono w tabeli nr 1. 
Tabela 1. Poziom PKB przypadający na mieszkańca w wybranych regionach UE oraz miejsce w rankingu HDI danego kraju

\begin{tabular}{|c|c|c|c|c|}
\hline \multirow[t]{2}{*}{ Region (kraj) } & \multicolumn{2}{|c|}{$\begin{array}{l}\text { Regionalny PKB (PPS na } \\
\text { jednego mieszkańca wyrażony } \\
\text { jako procent średniej dla UE }\end{array}$} & \multicolumn{2}{|c|}{$\begin{array}{c}\text { Miejsce kraju w rankingu } \\
\text { HDI Index }\end{array}$} \\
\hline & $2013 \mathrm{r}$. & $2015 \mathrm{r}$. & 2013 r. & $2016 \mathrm{r}$. \\
\hline Wiedeń (Austria) & 163 & 155 & 21 & 24 \\
\hline Region Stołeczny Brukseli (Belgia) & 211 & 205 & 21 & 22 \\
\hline Południowozachodni Region (Bułgaria) & 74 & 74 & 58 & 56 \\
\hline Chorwacja Kontynentalna (Chorwacja) & 60 & 59 & 47 & 45 \\
\hline Cypr (Cypr) & 84 & 81 & 32 & 33 \\
\hline Praga (Czechy) & 174 & 178 & 28 & 28 \\
\hline Region Stołeczny Danii (Dania) & 161 & 163 & 10 & 5 \\
\hline Estonia (Estonia) & 75 & 75 & 33 & 30 \\
\hline Helsinki-Uusimaa (Finlandia) & 149 & 144 & 24 & 23 \\
\hline Île-de-France (Francja) & 181 & 176 & 20 & 21 \\
\hline Attyka (Grecja) & 100 & 93 & 29 & 29 \\
\hline Madryt (Hiszpania) & 124 & 123 & 27 & 27 \\
\hline Groningen (Holandia) & 192 & 144 & 4 & 7 \\
\hline $\begin{array}{l}\text { Południowo-Wschodni region Irlandii } \\
\text { (Irlandia) }\end{array}$ & 148 & 153 & 11 & 8 \\
\hline Litwa (Litwa) & 73 & 75 & 35 & 37 \\
\hline Luxemburg (Luksemburg) & 261 & 264 & 21 & 20 \\
\hline Łotwa (Lotwa) & 62 & 64 & 48 & 44 \\
\hline Malta (Malta) & 86 & 93 & 37 & 33 \\
\hline Oberbayern (Niemcy) & 178 & 178 & 6 & 4 \\
\hline Mazowieckie (Polska) & 107 & 109 & 35 & 36 \\
\hline Lizbona (Portugalia) & 106 & 103 & 41 & 41 \\
\hline Bukareszt Ilfov (Rumunia) & 127 & 136 & 54 & 50 \\
\hline Kraj Bratysławski (Słowacja) & 189 & 188 & 37 & 40 \\
\hline Region Zachodnii (Słowenia) & 96 & 99 & 25 & 25 \\
\hline Sztokholm (Szwecja) & 173 & 174 & 12 & 14 \\
\hline $\begin{array}{l}\text { Region Centralny Közép-Magyarország } \\
\text { (Węgry) }\end{array}$ & 107 & 105 & 43 & 43 \\
\hline Londyn Wewnętrzny (Wielka Brytania) & 565 & 580 & 14 & 16 \\
\hline
\end{tabular}

Źródło: opracowanie własne na podstawie: Eurostat (2017), UNDP (2013, 2016).

Podczas analizy odnotowano ponad dwukrotnie wyższy poziom PKB od średniej UE-28 na obszarach: Londynu, Luksemburga oraz Brukseli. Warto również zaznaczyć, iż większość z 21 regionów UE, w których PKB na mieszkańca wynosił mniej niż połowę średniej, znajdowała się na obszarze Europy Wschodniej. W Polsce najlepiej rozwiniętym regionem, charakteryzującym się najwyższym poziomem PKB per capita, jest województwo mazowieckie. Natomiast wszystkie pozostałe obszary Polski zostały sklasyfikowane jako regiony słabiej rozwinięte. 
Warto zauważyć, że w krajach słabiej rozwiniętych, tj. Republice Czeskiej, Irlandii, Węgrzech, Polsce, Portugalii, Rumunii i Słowacji, jedynie regiony stołeczne należały do obszarów przekraczających średnią unijną. Państwa członkowskie, w których wszystkie regiony miały średni PKB na mieszkańca poniżej średniej UE to: Bułgaria, Grecja, Chorwacja, Słowenia i Węgry. Najlepiej rozwinięty region - Londyn Wewnętrzny- część zachodnia (539 \%), w którym PKB na mieszkańca był prawie 18 razy wyższy niż np. w regionie północno-zachodnim Bułgarii (30\%) (Komisja Europejska, 2014). Spadek poziomu PKB przed rozpoczęciem finansowania z programów zaplanowanych na lata 2014-2020 i rozpoczęciu finansowania (w najlepiej rozwiniętych regionach Państw UE), był skorelowany ze spadkiem w rankingu HDI (Austria, Belgia, Cypr, Francja, Holandia, Słowacja). Również wzrost poziomu PKB był skorelowany ze wzrostem HDI (Dania, Luksemburg, Łotwa, Malta, Rumunia).

W regionach, do których kierowanych jest najwięcej środków z Funduszu Spójności, odnotowuje się średni PKB na mieszkańca niższy niż 7 \% średniej dla UE-28. W okresie programowania 2014-2020 podstawę do celów finansowania ustalono w oparciu o średni poziom PKB na mieszkańca z trzyletniego okresu 2007-2009. W 21 regionach (z 78 o stosunkowo niskim PKB na mieszkańca) poziom produkcji gospodarczej na mieszkańca wynosił mniej niż połowę średniej UE-28. W tej grupie 19 regionów było położonych w Europie Wschodniej, w czterech państwach członkowskich UE: po pięć regionów w Bułgarii, Polsce i Rumunii oraz cztery na Węgrzech. Pozostałymi regionami były francuski region zamorski Majotta i grecki region Macedonia Wschodnia i Tracja - PKB na poziomie regionalnym (Eurostat, 2017).

\section{Podsumowanie}

Celem polityki regionalnej UE jest wzrost gospodarczy oraz poprawa jakości życia mieszkańców. Miernikiem wzrostu gospodarczego jest m.in. wielkość produkcji gospodarczej wyrażona poziomem PKB na mieszkańca. Spadek poziomu PKB w najlepiej rozwiniętych regionach był związany ze spadkiem wskaźnika rozwoju społecznego (w takich krajach jak: Austria, Belgia, Cypr, Francja, Holandia, Słowacja). Również wzrost poziomu PKB był skorelowany ze wzrostem w rankingu HDI. W krajach słabiej rozwiniętych tylko regiony stołeczne uzyskały poziom PKB per capita przekraczający średnią unijną (Republika Czeska, Irlandia, Węgry, Polska, Portugalia, Rumunia i Słowacja). Regiony, w których odnotowano średni poziom produktu krajowego brutto na mieszkańca poniżej średniej UE to: Bułgaria, Grecja, Chorwacja, Słowenia i Węgry. 
W głównej mierze finansowane ze środków UE są najbiedniejsze regiony zlokalizowanych w Europie Wschodniej (Polska, Węgry, Bułgaria i Rumunia). Jednakże w okresie 2013-2016 jedynie Rumunia i Bułgaria zostały lepiej ocenione pod względem rozwoju społecznego. Polska w analizowanym okresie spadła o jedną pozycję w rankingu. Warto zaznaczyć, że PKB nie jest bezpośrednio wskaźnikiem jakości życia, natomiast w słabiej rozwiniętych regionach wzrost PKB może odzwierciedlać zmiany ekonomiczne (wzrost gospodarczy) a tym samym pośrednio wskazywać na wzrost jakości życia (Rumunia, Bułgaria). W gronie najlepiej rozwiniętych państw świata poziom PKB nie musi odzwierciedlać poziomu jakości życia (tak jak pokazuje to przykład Niemiec). Decydujące zatem będę pozostałe czynniki jak długość życia czy też poziom edukacji.

\section{Literatura}

Begg, D., Vernasca, G., Fischer, S., Dornbusch, R. (2011). Makroekonomia: PWE.

Diener, E., Oishi, S., Lucas, R. (2009). Subjective Well-Being: The Science of Happiness and Life Satisfaction. W: The Oxford Handbook of Positive Psychology. Oxford: University Press. Pobrane z: http://greatergood.berkeley.edu/images/application_uploads/Diener-Subjective_Well-Being.pdf (10.09.2017).

EuroLex (2017). Traktaty Rzymskie, Traktat ustanawiajacy Europejska Wspólnote Gospodarcza. Pobrane z: https://eures.praca.gov.pl/zal/podstawy_prawne/Traktat_rzymski. pdf (10.09.2017).

Europejski Fundusz Rozwoju Regionalnego (2017). Fundusze Strukturalne. Pobrane z: http:// www.fundusze-strukturalne.pl/efrr.html (15.09.2017).

Eurostat (2017a). PKB na poziomie regionalnym. Brussels: European Commission. Pobrane z: http://ec.europa.eu/eurostat/statisticsexplained/index.php/GDP_at_regional_level/ pl\#PKB_na_poziomie_regionalnym (5.09.2017).

Eurostat (2017b). Regional gross domestic product (PPS per inhabitant in \% of the EU28 average) by NUTS 2 regions. Brussels: European Commission.

Kolman, R. (2002). Zespoły badawcze jakości życia. Problemy Jakości, 2 (32), 2-5.

Komisja Europejska (2017). Główna polityka inwestycyjna UE. Bruksela. Pobrane z: http:// ec.europa.eu/regional_policy/pl/policy/what/investment-policy/ (12.09.2017).

Komisja Europejska (2014). Polityka regionalna. Zwiększenie konkurencyjności regionów i miast europejskich, wspieranie rozwoju i tworzenie miejsc pracy. Bruksela. Pobrane z: https://europa.eu/european-union/file/1435/download_pl?token=uGPauAoh.

Meyer, B. (1999). Gospodarka przestrzenna. Mechanizmy rozwoju, teorie i systemy. Szczecin: PTO.

Tomcz-Tołkacz, J. (2003). Jakość życia w perspektywie nauk humanistycznych, ekonomicznych i ekologii. Wrocław: Akademia Ekonomiczna im. Oskara Langego. 
Tomaszewski, T. (1984). Główne idee współczesnej psychologii. Warszawa: Wydawnictwo Omega.

WHOQOL Group (1995). The WHO Quality of Life Assesement: Position Paper of the WHO. Social Science and Medicine, 10 (41), 1403-1309.

UNDP (2016). Human Development Raport 2016. Human Development for Everyone. New York, USA. Pobrane z: http://hdr.undp.org/sites/default/files/2016_human_development_report.pdf (1.09.2017).

Unia Europejska (2017). Życie w UE. Bruksela. Pobrane z: https://europa.eu/european-union/ about-eu/figures/living_pl\#tab-5-11 (1.09.2017).

\section{Cytowanie}

Szulc-Fischer, P. (2017). Wpływ finansowania ze środków Unii Europejskiej na jakość życia mieszkańców. Europa Regionum, 4 (XXXIII), 137-147. DOI: 10.18276/er.2017.33-13. 
